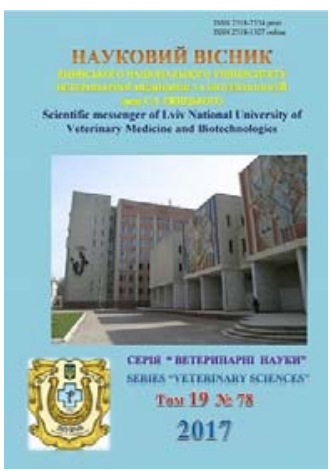

Науковий вісник Львівського національного університету ветеринарної медицини та біотехнологій імені С.З. Гжицького

Scientific Messenger of Lviv National University of Veterinary Medicine and Biotechnologies

doi:10.15421/nvlvet7823

ISSN 2518-7554 print

ISSN 2518-1327 online

$\underline{\text { http://nvlvet.com.ua/ }}$

УДК 619:616.99:636.028

\title{
Експериментальне зараження каченят метацеркаріями трематод Cryptocotyle Lühe, 1899 (Trematoda: Heterophyidae)
}

\author{
С.Л. Гончаров \\ sergeyvet85@ukr.net
}

Миколаївський національний аграрний університет,

вул. Георгія Гонгадзе, 9, м. Миколаїв, 54000, Україна

\begin{abstract}
У статті наведено дані щодо результатів експериментального зараження піддослідних каченят метацеркаріями трематод родини Неterophyidae, щчо були відібрані від риб, представників Gobiidae: Mesogobius batrachocephalus Pallas, 1814, Neogobius melanostomum Pallas, 1814, Neogobius fluviatialis Pallas, 1814. Риба була виловлена в акваторіях Чорного моря $i$ Дніпро-Бузького лиману Миколаївської та Одеської областей. Описано патологічні прочеси, щцо виникають у піддослідних птахів у результаті захворювання на криптокотильоз. При уражені шлунково-кишкового каналу каченят трематодами родини Неterophyidaе виявлено патолого-анатомічні симптоми гострого катарального ентериту, який проявлявся ураженням слизової оболонки тонких кишок, набряком, гіперемією та утворенням крапкових $i$ смугоподібних крововиливів на поверхні останніх. Також виявлено ураження печінки інвазованих каченят. Встановлено, щзо відсоток виживаності трематод в організмі каченят після 25 діб зараження становить 83. Виявлено, щь на території Миколаївської та Одеської областей у природних водоймах ичикулюють два види трематод родини Heterophyidae: Cryptocotyle cancavum Crepli, 1825 та Cryptocotyle jejuna Nicoll,1907. Останній вид раніше не реєструвався на зазначеній ділянці території півдня Украӥни.

Ключові слова: експериментальне зараження, каченята, С. јејипа, С. сапсалит, риба, виживаність, патологоанатомічні зміни, Чорне море, Дніпро-Бузький лиман, Миколаївська та Одеська області.
\end{abstract}

\section{Экспериментальное заражение утят метацеркариями трематод Cryptocotyle Lühe, 1899 (Trematoda: Heterophyidae)}

\author{
С.Л. Гончаров \\ sergeyvet85@ukr.net
}

Николаевский национальный аграрный университет,

ул. Георгия Гонгадзе 9, г. Николаев, 54000, Украина

\begin{abstract}
В статье приведены данные результатов экспериментального заражения подопытных утят метацеркариями трематод семейства Heterophyidae, отобранных от рыб, представителей Gobiidae:Mesogobius batrachocephalus Pallas, 1814, Neogobius melanostomum Pallas, 1814, Neogobius fluviatialis Pallas, 1814. Рыба была выловлена в акваториях Черного моря и Днепро-Бугского лимана Николаевской и Одесской областей. Описаны патологические процессы, возникающие у подопытных птии в результате заболевания криптокотильозом. При поражении желудочно-кишечного тракта утят трематодами семейства Неtеrophyidaе обнаружено патолого-анатомические симптомы острого катарального энтерита, который проявлялся поражением слизистой оболочки тонкого кишечника, отеком, гиперемией и образованием точечных и полоскообразных кровоизлияний на поверхности последних. Также выявлено поражение печени инвазированных утят. Установлено, что процент выживаемости трематод в организме утят после 25 суток заражения составляет 83\%.Установлено, что на территории Николаевской и Одесской областей в естественных водоемах ииркулируют два вида трематод семьи Heterophyidae: Cryptocotyle cancavum Crepli, 1825 и Cryptocotyle jejuna Nicoll, 1907. Последний вид ранее не регистрировался на данном участке территории юга Украины.
\end{abstract}

Citation:

Goncharov, S.L. (2017). Experimental infection of ducklings with trematodes Cryptocotyle Lühe, 1899 (Trematoda: Heterophyidae) metacercariae. Scientific Messenger LNUVMB, 19(78), 112-117. 
Ключевые слова: экспериментальное заражение, утята, С. јејипа, С. сопсауит, рыба, выживаемость, патологоанатомические изменения, Черное море, Днепро-Бугский лиман, Николаевская и Одесская области.

\title{
Experimental infection of ducklings with trematodes Cryptocotyle Lühe, 1899 (Trematoda: Heterophyidae) metacercariae
}

\author{
S.L. Goncharov \\ sergeyvet85@ukr.net \\ Mykolayiv National Agricultural University, \\ Georgiy Gongadze Str., 9, Mykolayiv, 54000, Ukraine
}

\begin{abstract}
The results of experimental infection of ducklings with metacerciae of the trematodes of the Heterophyidae family, obtained from the fish, are given in the article. Following species were studied: Mesogobius batrachocephalus Pallas, 1814, Neogobius melanostomum Pallas, 1814, Neogobius fluviatialis Pallas, 1814. Fish were caught in the waters of the Black Sea and the Dnipro-Bug estuary of Mykolayiv and Odesa regions. The pathological changes occurring in experimental birds as a result of a cryptocotyle infection are described. The pathomorphological features of acute catarrhal enteritis cause by trematodes Heterophyidae family were found. They included lesions of the small intestine mucosa, edema, hyperemia and the formation hemorrhages on the mucosal surface. Liver injury was observed as well. It was found that the percentage of survival of trematodes in the body of ducklings after 25 days of infection is $83 \%$. It was found that in the area of the Mykolaiv and Odesa regions in the natural reservoirs two types of trematodes of the Heterophyidae family are circulating: Cryptocotyle concavum Crepli, 1825 and Cryptocotyle jejuna Nicoll, 1907. The latter species was previously not registered in this part of southern Ukraine.

Key words: experimental infection, ducklings, C. jejuna, C. concavum, fish, survival, pathomorphological features, Black Sea, Dnipro-Bug estuary, Mykolayiv and Odesa regions.
\end{abstract}

\section{Вступ}

Паразитози є проблемою, що стримують подальший розвиток рибних господарств, які розводять і вирощують товарну рибу, нарощування об'ємів рибної продукції, поліпшення іiі якості та збільшення економічної ефективності галузі. Тому досить важливо шукати все нові й нові шляхи для досягнення ефективного контролю за небезпечними паразитарними хворобами риб. На часі стає актуальним вивчення ситуації щодо поширення небезпечних збудників, їх біології, патогенезу та особливостей перебігу паразитарних хвороб у риб (Sudarikov, 2006).

Відомо, що найбільш тісні взаємини паразитів 3 хазяями бувають тоді, коли ті оселяються безпосередньо у їх тканинах. У таких випадках найбільш гостро відчувається негативний вплив паразитів на гомеостаз організму хазяїна через механічні пошкодження тканин, порушення обмінних процесів та роботи імунної системи, що нерідко супроводжуються важкими клінічними проявами та високою летальністю (Gardner and Thew, 2006; Sudarikov, 2006). Саме такими паразитами риб є метацеркарії родини Heterophyidae.

Це трематоди, першими проміжними хазяями яких $\epsilon$ черевоногі молюски, а остаточними - рибоїдні птахи (Radulescu and Vasiliu, 1951; Gardner and Thew, 2006; Martynenko, 2012). Досі лишається недостатньо вивченим поширення криптокотильозу риб в Україні. Не 3'ясовано багато питань щодо біології збудника. Неоднозначно висвітлено у літературі патогенний вплив цього паразита на організм хазяїна. Не досліджено повною мірою патогенез та невідомо про роль різних рибоїдних птахів у циркуляції паразита. Існує також ймовірність зараження людини як потенційного остаточного хазяїна для даного паразита (Radulescu and Vasiliu, 1951).
Завданням роботи було дослідити можливість експериментального зараження піддослідних каченят метацеркаріями трематод родини Heterophyidae, що були відібрані від бичкових риб, виловлених в акваторіях Чорного моря і Дніпро-Бузького лиману Миколаївської і Одеської областей та відтворити криптокотильоз у птахів. Також описати можливі патологічні процеси, що виникають у піддослідних птахів у результаті захворювання на криптокотильоз. Встановити відсоток виживаності трематод в організмі каченят та можливість паразита досягати статевозрілої стадіїмарити в організмі дефінітивного хазяїна.

\section{Матеріал і методи дослідження}

Протягом 2015-2016 рр. було досліджено 572 екземпляри бичків різних видів. При проведенні розтину відбирали тканини та досліджували компресорним методом за допомогою компресорію МИС-7. Виявляли метацеркарії на поверхні тіла, плавцях, а також на зябрах риб родини Gobiidae: M. batrachocephalus, N. melanostomum, N. fluviatialis (рис. 1).

Відбір зразків проводили вздовж берегової лінії Чорного моря, а також у ділянці Дніпро-Бузького лиману, в адміністративних кордонах Миколаївської області та у частині акваторії Чорного моря, що адміністративно розташована в Одеській області.

3 метою досконалого вивчення анатомоморфологічних особливостей гельмінта та більш точного визначення таксономічної належності проводили зараження каченят. Для проведення експериментального зараження використовували 20 каченят пекінської породи 15-денного віку. Каченята були одного віку та масою 285-370 г.

Каченят розподіляли за принципом аналогів на 2 групи, по 10 голів у кожній $(\mathrm{n}=20)$. Перша група піддавалсь інвазуванню метацеркаріями. Експеримен- 
тальній групі каченят згодовували відібрані тканини, що містили метацеркарії трематод родини Heterophyidae, по 100 метацеркаріїв кожному птаху та очікували 25 діб. Друга група каченят була контрольною.

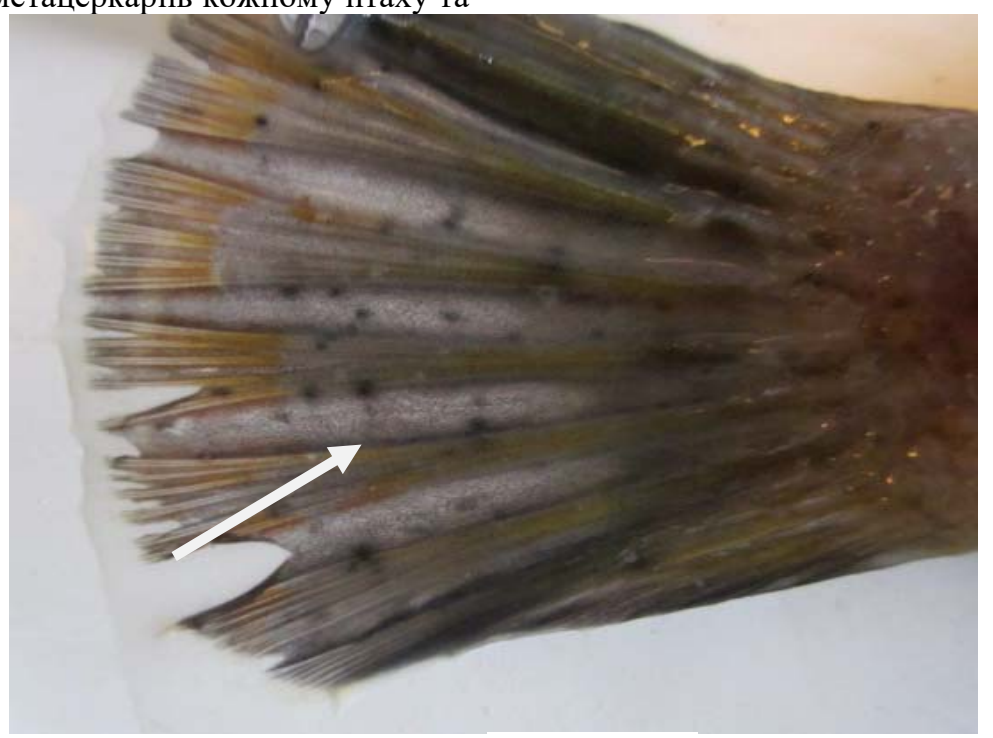

Рис. 1. Метацеркарії трематоди родини Heterophyidae на хвостовому плавці $N$. fluviatialis

Зараження каченят проводили у травні. Каченят утримували у приміщенні віварію Миколаївської регіональної державної лабораторії ветеринарної медицини, у сітчастих клітках, окремо кожну піддослідну групу. Середньодобова температура у приміщенні становила $18{ }^{\circ} \mathrm{C}$. Годівля каченят проводилась згідно з наказом Міністерства охорони здоров'я СРСР № 163 від 10.03.1966 року «Про норми годівлі лабораторних тварин і продуцентів». В складі раціону були концентровані корми та зерносуміш - 39,6\%, зелень та соковиті корми - 57\%, корми тваринного походження (кісткове та рибне борошно) - 2,14\%, мінеральні речовини (крейда) - 1,06\%; сіль кухонна $0,11 \%$. Напування проводили 3 автоматичних напувалок. Воду змінювали щодня. 3 метою забезпечення задовільних гігієнічних умов, прибирання кліток здійснювали щодня протягом часу спостереження за піддослідними каченятами.

По закінченні визначеного періоду - 25 діб, каченят піддавали евтаназії за допомогою наркотизації етиловим ефіром для проведення розтину та подальшого патоморфологічного і паразитологічного дослідження шлунково-кишкового каналу на предмет наявності статевозрілих трематод.

Виділених метацеркаріїв і статевозрілих трематод промивали у фізіологічному розчині, фарбували квасцевим карміном, диференціювали в розчині солянокислого спирту, зневоднювали у спиртах зростаючої концентрації, просвітлювали у гвоздичній олії та заливали у бальзам.

Дослідження проводили відповідно до вимог «Свропейської конвенції про захист хребетних тварин, які використовуються 3 експериментальною та іншою науковою метою» (Страсбург, 1986).

\section{Результати та їх обговорення}

При мікроскопії гепатопанкреаса, жовчного міхуpa, кришталика ока, а також тканин серця, нирок, мозку метацеркаріїв не виявляли. Водночас при мікроскопії поверхневих тканин, відібраних з різних ділянок тіла риби, зокрема плавців та зябер, знаходили метецеркарії $C$. jejuna i $C$. concavum.

Ексцистовані метацеркарії $C$. concavum мали тіло овальної форми, завдовжки 0,42 мм, завширшки 0,37 мм. Кутикула була щільна, вкрита дрібними шипиками. Ротова присоска термінальна, округла, 0,055 мм у діаметрі. Префаринкс короткий - 0,011 мм, фаринкс овальний, 0,038 мм; за ним - розгалуження кишкової трубки, стовбури якої направлені до каудальної частини тіла та сліпо закінчуються позаду сім'яників. Статевий синус 3 рудиментарною черевною присоскою, округлої форми, міститься у задній частині тіла. Екскреторний орган відкривається на кінці тіла.

Велику зацікавленість становили метацеркарії C. јејипа, оскільки раніше в акваторіях зазначеної ділянки природних водойм півдня України їх не реєстрували. Цисти у них мали овальну форму. Тіло метацеркарія було видовжено-овальної форми, дещо загострене спереду та заокруглене ззаду. Кутикула вкрита дрібними шипиками. Ротова присоска субтермінальна, 0,048 мм. Префаринкс добре виражений, 0,013 мм, фиринкс невеликий, шароподібний. Стравохід за довжиною дорівнює префаринксу. Кишкові стовбури добре візуалізуються та сліпо закінчуються в задній частині тіла, огинаючи зародки сім'яників (Naydenova, 1974; Gibson et al., 2005).

Після експериментального зараження каченят метацеркаріями $C$. јејипа очікування тривало 25 діб. Починаючи вже з 3 доби у деяких каченят відмічали слабкість, пригнічення та пронос. Цікаво відмітити, що у рідких калових масах при додатковому дослідженні знаходили недорозвинуті трематоди $C$. јејuna, які, вочевидь, елімінувалися під впливом підвищеної перистальтики кишок каченят. У подальшому, починаючи з 5 доби, при проносах елімінацію паразитів не фіксували. Це, ймовірно, свідчить про те, що з цього 
часу паразити надійно фіксувалися на слизовій оболонці до слизової оболонки кишок, росли і розвивалися. Загибелі каченят не відмічали.

При патолого-анатомічному розтині експериментально заражених каченят реєстрували гострий катаральний ентерит. Вміст кишок був заповнений масами брунатного кольору та неприємного запаху. Слизова оболонка кишок була складчаста та запалена. Ознаки запалення проявлялися у повнокровності, набряку та гіперемії слизової оболонки. Вона була вкрита великою кількістю тягучого серозно-слизового ексудату та мала драглисту консистенцію. Також на поверхні слизової оболонки виявляли крапкові та смугоподібні крововиливи (рис. 2).

Також відмічали нерівномірне забарвлення печінки, в'ялість, на розрізі паренхіми - випинання країв за межі капсули органу. Даний процес, вочевидь, $є$ наслідком токсичного впливу паразита та продуктів його життєдіяльності на організм піддослідних каченят (рис. 3).

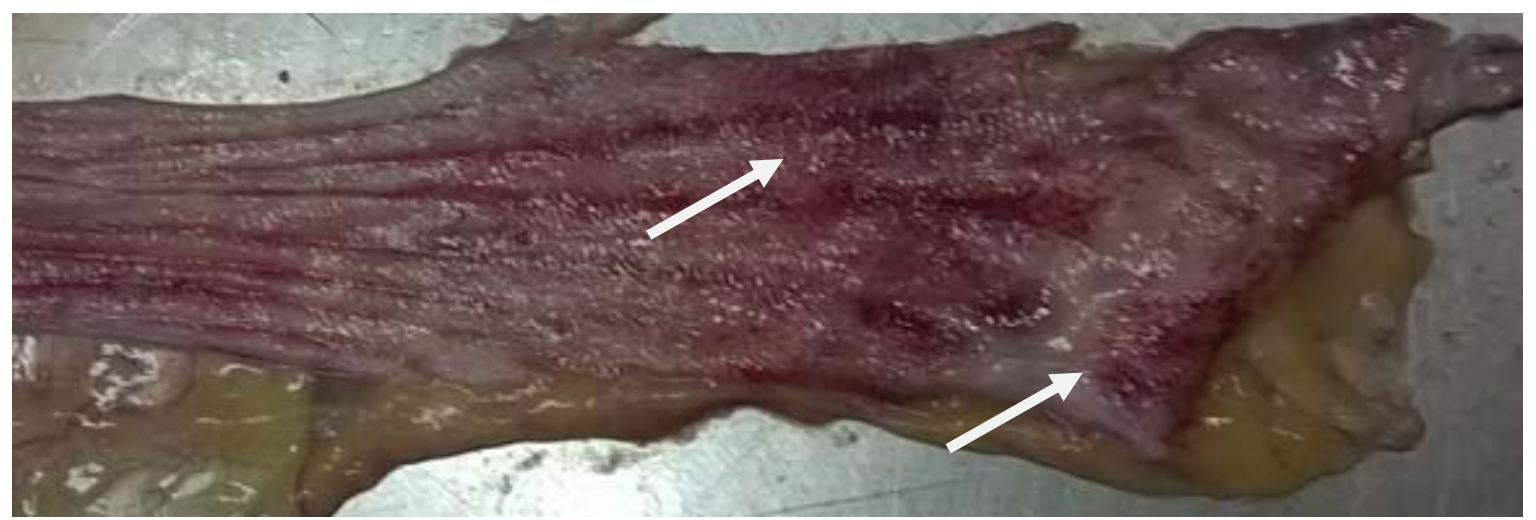

Рис. 2. Ознаки гострого катарального ентериту на слизовій оболонці тонких кишок каченяти

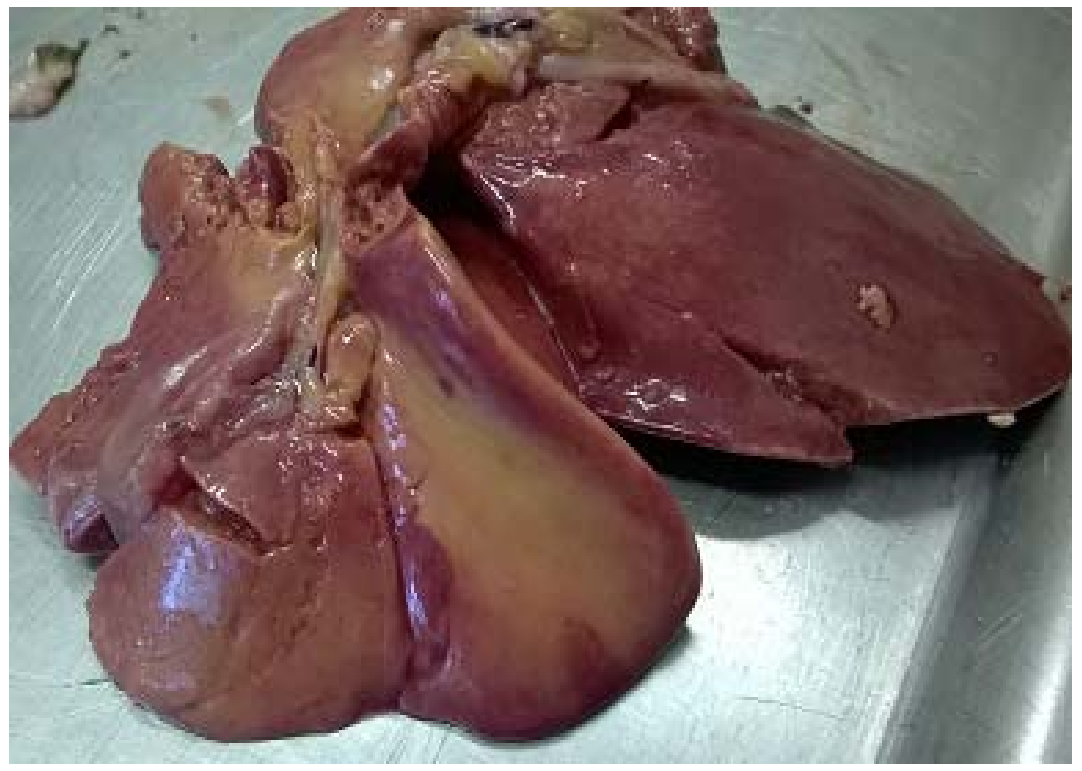

Рис. 3. Печінка піддослідного каченяти за експериментального криптокотильозу

На поверхні слизової оболонки кишок, без використання оптичної техніки, знаходили трематод. Вони були добре помітні через свою рухливість та сильно виражений в екскреторний міхур (рис. 4).

Відібраних трематод промивали у фізіологічному розчині та фарбували квасцевим карміном за Гренахером за загальноприйнятою методикою (Sudarikov, 2006). Статевозрілі трематоди $C$. јејипа мали витягнуте тіло, 0,94-1,47 мм завдовжки та 0,3-0,5 мм завширшки. Їх кутикула вкрита дрібними шипиками. Ротова присоска субтермінальна, 0,085-0,072 мм у діаметрі. Черевна присоска рудиментарна та вкрита мембраною. Статева присоска мала вигляд сосочка, що складається 3 двох частин. Поряд зі статевою присоскою в генітальному синусі відкривається статевий отвір. Префаринкс порівняно широкий, фиринкс овальної форми - 0,062 мм. Стравохід довгий. Водночас біфуркація кишкової трубки розташована ближче до ротової присоски, ніж до черевної. Кишкові гілки тягнуться по боках майже до заднього краю тіла. Сім'яники трикутні, розміщені у задній частині тіла. Лівий сім'яник більший за правий, розміром 0,121 та 0,085 мм відповідно. Сім'яний міхур представлений видовженою трубкою, розміщений на рівні яєчника. Водночас яєчник лежить позаду правого сім'яника та має неправильну трикутну форму, розміром $0,68 \times$ 0,101 мм. Жовтяник складається 3 дрібних фолікулів, які тягнуться до заднього краю тіла і з'єднуються між 
собою перетяжкою. Матка займає простір між лівим сім'яником, яєчником та генітальним синусом і між гілками кишкової трубки. Яйця 0,03-0,034 мм. Екск- реторний міхур з S-подібним стовбуром, що згинається між сім'яниками, від нього відходять дві гілки (n = 24) (рис. 5) (Gibson et al., 2005).

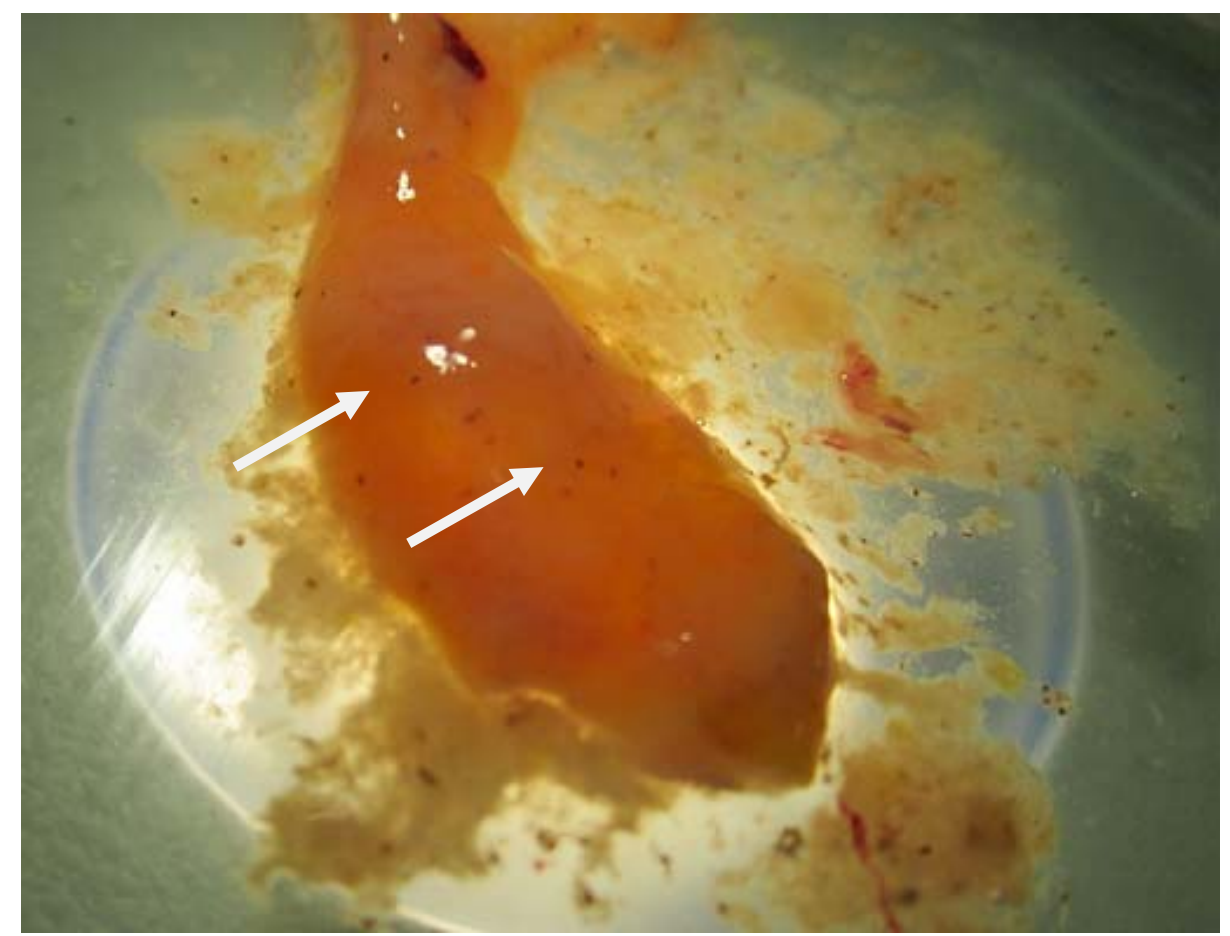

Рис. 4. Ділянка тонких кишок каченяти на розтині. Добре помітні трематоди $C$. јејипа в слизу та на поверхні слизової оболонки

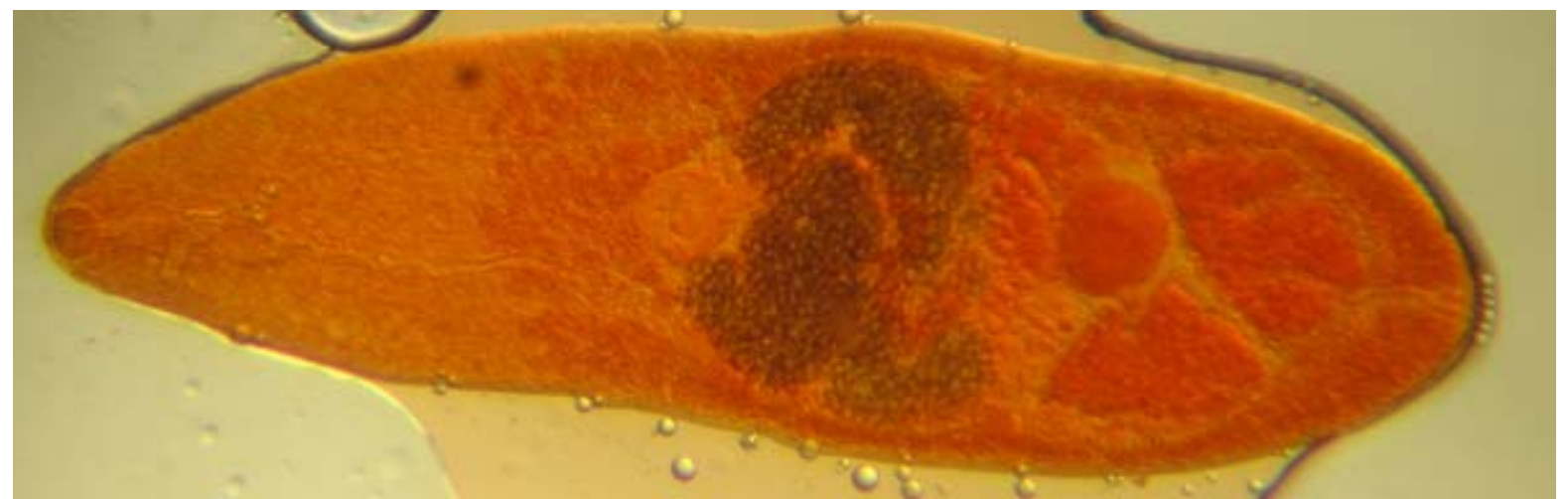

Рис. 5. Трематода $C$. јејипа. Забарвлення квасцевим карміном за Гренахером. Збільшення 10 х 40

У піддослідних птахів першої групи виявляли статевозрілих тремадот, що локалізувалися у шлунковокишковому каналі. Інтенсивність інвазії була неоднаковою та становила: у першого каченяти - 79, у другого - 82 марити C. јејuna.

При розтині третього птаха першої групи було виявлено 68 , четвертого - 92, п'ятого - 77, шостого - 85 , сьомого - 90, восьмого - 83 статевозрілих трематод. У дев'ятого та десятого каченяти інтенсивність інвазії становила по 87 паразитів відповідно.

Під час проведення патолого-анатомічного розтину другої, контрольної, групи каченят ознак паразитарної інвазії та запальних процесів шлунковокишкового каналу не виявляли.

\section{Висновки}

1. За результатами досліджень встановлено, що виживаність трематод в I групі піддослідних каченят становила $83 \%$. Друга група була контрольною.

2. Вочевидь, при інтенсивному інвазуванні каченят збудником криптокотильозу в перші дні певна кількість трематоди елімінується з каловими масами при діареї.

3. При паразитуванні C. јејипа було встановлено негативний вплив на організм інвазованих каченят, а саме: слабкість, знижений апетит, діарея, відставання у рості порівняно 3 контрольною групою. Загибелі каченят за час проведення експериментального зараження не було.

4. Виявлено патологічний вплив паразита на організм каченят: ураження кишок та печінки. 
5. Описано трематоди C. јејuna - вид, що раніше не реєструвався на зазначеній ділянці території півдня України.

\section{Бібліографічні посилання}

Byhovskaja-Pavlovskaja, I.E. (1985). Parazity ryb. Rukovodstvo po izucheniju. L.: Nauka (in Russian).

Naydenova, N.N. (1974). Parazytofauna ryb semeystva bychkovykh Chornoho y Azovskoho morey. Kyev: «Naukova dumka» (in Ukrainian).

Sudarikov, V.E. (2006). Metacerkarii trematod - parazity ryb Kaspijskogo morja i del'ty Volgi. M.: Nauka. 2, 183 (in Russian).

Gardner, S.L., Thew, P.T. (2006). Redescription of Cryptocotyle thapari McIntosh, 1953 (Trematoda: Hetero- phyidae), in the river Otter Luttra longicaudis from Bolivia. Comparative Parasitoligy. 73, 20-23.

Gibson, D.I., Jones, A., Bray, A. (2005). Keys to the Trematoda. Wallingford: CABI Publ. 2, 768.

Martynenko, I.M. (2012). On the finding Cryptocotyle jejuna (Nicoll, 1907) Ransom, 1920 in the Kerch Strait. Reports of the conference of young researchers zoologists. Institute of Zoology NAS of Ukraine. Kiev. 21.

Radulescu, I., Vasiliu, N. (1951). Infestatie masiva cu ectoparaziti la stronghil (Neogobius melanostomus Pall). Bull. Inst. Cer. Pesc. 10(4), 59-66.

Received 25.09.2017 Received in revised form 13.10.2017 Accepted 16.10.2017 